\title{
Physician turnover in primary health care services in the East Zone of São Paulo City, Brazil: incidence and associated factors
}

\author{
Monique M. M. Bourget ${ }^{1 *}$, Alex J. F. Cassenote $2,3,4,5$ and Mário C. Scheffer ${ }^{1,3,4}$
}

\begin{abstract}
Background: The shortage and high turnover of physicians is a recurrent problem in health care systems; this is especially harmful to the expansion and full operation of primary health care (PHC). The aim of this paper is to analyze incidence and associated factors with physician turnover in primary health care services in the East Zone of São Paulo City.

Methods: This is a retrospective cohort study of 1378 physicians over a 15 years' time period based on physicians' administrative records from two distinct secondary databases. Physicians' individual characteristics were analyzed including graduation and specialization. Survival analysis techniques such Kaplan-Meier and Cox Regression were used to analyze the termination of contract.
\end{abstract}

Results: One thousand three hundred seventy-eight physicians were included in the study of which 130 [9.4\%(C195 8.0-11.1\%)] remained in the PHC services. The mean and median time until the occurrence of the physician leaving the service was 2.14years (CI95\% 1.98-2.29years) and 1.17years [(CI95\% 1.05-1.28years)]. The probability of contract interruption was $45 \%$ in the first year and $68 \%$ in the second year. Independent factors associated with TEC were identified: workload of $40 \mathrm{~h} /$ week HR $=1.71$ [(Cl95\% 1.4-2.09), $p<0.001]$; initial salary $\leq 1052 \mathrm{BGl} \mathrm{HR}=1.87$ [(Cl95 $1.64-2.15), p<0.001]$; time since graduation $\leq 2$ years $\mathrm{HR}=1.36$ [(Cl95 1.18-1.56), $p<0.001]$; and the conclusion of residency in up to 3 years after leaving the service $H R=1.69$ [(C195 1.40-2.04), $p<0.001]$.

Conclusions: The time of employment of the physician in PHC was relatively short, with a high probability of TEC in the first year. Modifiable factors such as working hours, starting salary, time since graduation from medical school and need to enter in a residency program were associated with TEC. In pointing out that modifiable factors are responsible for long term employment or the end of contract of physicians in PHC services of the Unified Health System in the periphery of a metropolitan area, the study provides support for the planning, implementation and management of policies and strategies aimed at attracting and retaining physicians in suburban, priority or underserved regions.

Keywords: Employment, Physicians, Primary health care, Personnel turnover, Health centers, Survival analysis

*Correspondence: bourgetmonique25@gmail.com

1 Program of Collective Health, Faculty of Medicine of the São Paulo University (FMUSP), São Paulo, SP, Brazil

Full list of author information is available at the end of the article

\begin{abstract}
Background
Health professionals are the cornerstone of health care systems and contribute to the development of nations, representing more than $10 \%$ of total employment in many countries [1-3]. The composition of the workforce in health and the mechanisms to guarantee financial sustainability has mobilized international organizations and
\end{abstract}


leaders in health care all over the world. The great challenge is to have a workforce that is qualified, sufficient, permanent and adequate to each environment [4-8].

Workforce depends on many factors like the political system of the country, national policy; educational system, quality of training; country's economy and financing of the educational and health care system; waging policies, working conditions, distribution and insertion of professionals in the system. Additional topics include epidemiology and demographics, legislation, practice regulations and professional councils and popular councils, covenant and agreement between parties [9-14]. Worldwide, half the population lives in poor areas but only $23 \%$ of health professionals are located in these same poor areas, hence, there are many care gaps [15-19]. This study will try to identify the factors that could help retain the profissionals.

The working place of a physician is a complex and multifactorial choice. Some of the issues are lack of attractiveness for living and working conditions, forms of employment, contracts and remuneration of professionals, lower prestige and professional status in relation to primary care medical activities and specialties, lower attraction to more remote regions which may be perceived to have less educational, cultural and demographic opportunities; in addition, less health resources and high disease burden make provision of health care more challenging [20-23].

PHC is a key element to the constitution of national health care systems, with the capacity to impact positively on health indicators and with a great potential to assist in the optimal use of resources and organize the network. PHC has become responsible for the organization of health care of individuals, families and the population over time, leading to better health indicators, improved efficiency and lower costs to the system [24-26].

In Brazil, The Family Health Strategy (FHS) is a strategic program of the Brazilian Unified Health System (UHS) that initiated in 1994 and over the last 25 years has rapidly expanded. This policy had a positive impact on population's access to health services, leading to a massive growth in the number of medical consultations per capita between 1990 and 2009; there has been a remarkable diminution of over $70 \%$ of infant mortality and of hospitalization for strokes and acute respiratory infections [27-30]. However, one of the big challenges of PHC has been the high turnover and subsequent lack of medical workforce, which resulted in the inability to further expand the FHS in many locations [31-33].

The difficulties of attracting and retaining medical professionals, especially in PHC, in Brazil and in other countries, have been the subject of several studies [16, 34-39].
Similar to other countries [40, 41], doctors in Brazil have multiple jobs, great mobility throughout their professional career and different possibilities of insertion in a segmented health system where the public and private sectors are in constant interaction and overlapping [4244]. More than $50 \%$ of Brazilian physicians provide care in both public and private sectors [45] which may contribute to reducing the supply of doctors and service in the public sector; this can potentially adversely impact on the expansion capacity of $\mathrm{PHC}$, accessibility and quality of care in public health care system [26]. The aim of this paper is to analyze incidence and associated factors with physician's turnover in primary health care services in East Zone of São Paulo City which adopted a public-private partnership with many institutions since 2001, and Santa Marcelina Institution was the first one to sign such a contract of the management of the health care units. A study of this magnitude was unprecedented in Brazil, and also intended to contribute to the gap of individual factors that impact the turnover of professionals in the service in which they are inserted.

\section{Methods}

Study design, research scenario and ethical consideration

This is a retrospective longitudinal cohort study without a control group developed in the East Zone of São Paulo City, Brazil (Fig. 1).

The East Zone has great relevance to municipal health because of its high population density: in the last census of 2010 , about $3,998,237$ million people live in the region (35.5\% of the total population of the capital - 11,253,503) [46]. With a large geographical extension, it concentrates the lowest per capita income of the municipality, has a high poverty rate and health problems common to the most peripheral regions and of high economic and social vulnerability. Most districts in the east have a human development index-HDI below the municipality and state average [47]. 70\% of all health units are sob a contract managed by the Santa Marcelina institution (117 units of which 56 operate with FHS teams).

\section{Databases, inclusion criteria and ethical considerations}

The main database was provided by the Santa Marcelina Human Resources Management Department and included information on the functional and administrative registration of physicians who have worked at PHC services administered by the Institution between 2001 and 2016. All variables that carry labor information originated from this database.

The second database was obtained from the study on Medical Demography In Brazil, which included demographic data from all physicians registered at the Medical Regional Councils (CRMs), as well as data from the 


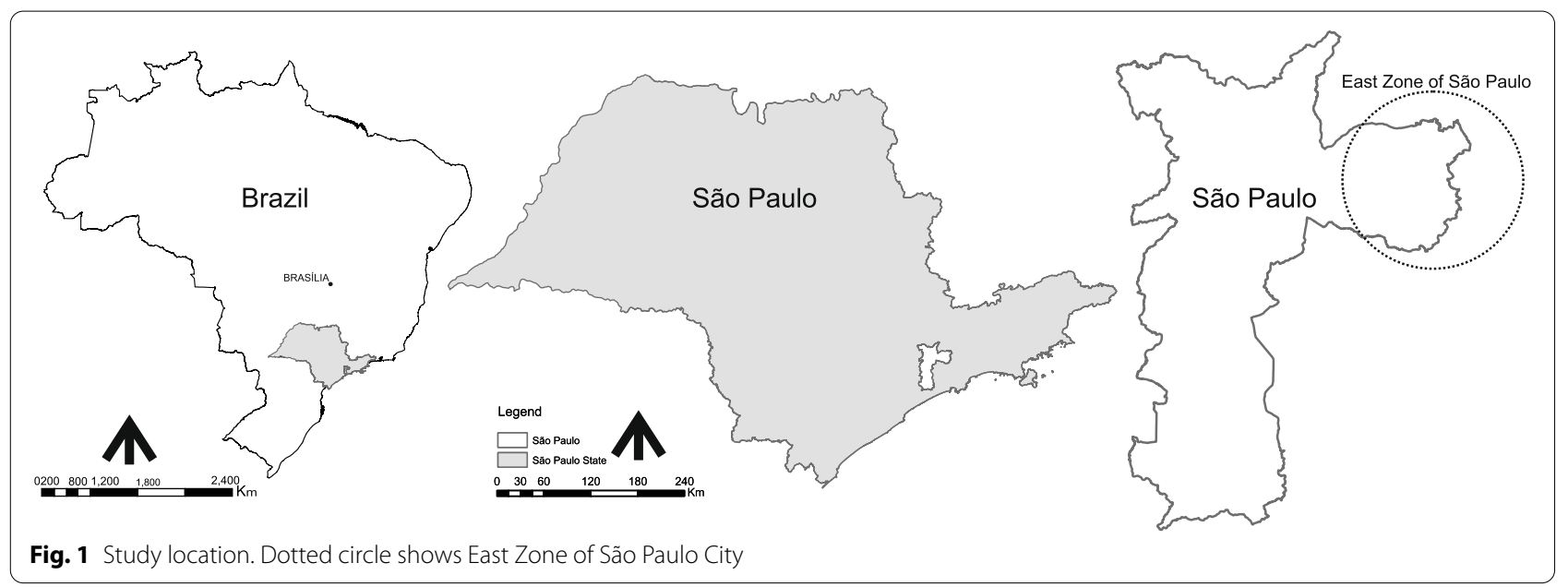

National Commission of Medical Residency (CNRM) and all the Medical Specialty Societies associated to the Brazilian Medical Association (AMB).

All 1378 physicians admitted between January 1rst of 2001 and December 31rst of 2016 who worked or were still working in PHC in the East Zone of the city of São Paulo, Brazil, in a Traditional Health Care Unit or a Unit operating the Family Health Strategy, were included. This paper was performed in accordance with STROBE Statement for cohort studies.

The research followed all ethical parameters required by the Resolution $N^{\circ} 466 / 2012$ of the National Research Ethics Commission of the National Health Council and was approved by the Research Ethical Committee of the Medical Faculty of São Paulo University (\#66147417.0.0000.0065). Prior to the start this study, written consent and the required administrative permissions were obtained from the Santa Marcelina authorities to access human resource data. The IRB waived the use of the informed consent because the data accessed did not contain information that would allow personal identification. Confidentiality and privacy of all physician's data was ensured, used solely and exclusively as a whole for statistical purposes.

\section{Variables and outcome definitions}

After standardization of nomenclatures and typing in the final database, 15 variables were defined for study: work time, termination of contract (TEC), gender, age, year of initial employment date, weekly workload, place of work, initial salary at employment date, time frame since graduation at the time of initial employment, city of residency, type of graduation school, city of graduation, specialty on initial employment date, specialty at the present moment and medical residency after employment. The definitions and details of the variables are described in detail in the supplementary material.

\section{Data analysis}

Descriptive statistics including absolute and relative frequencies and $95 \%$ confidence intervals $(95 \% \mathrm{CI})$ were used. Estimates of the average time until the occurrence of the TEC, including a $95 \%$ confidence interval (95\% CI) were calculated using Kaplan-Meier and for testing the hypothesis that the different factors had no impact on "survival", a log rank statistic was used.

Cox regression was used to evaluate the multiple influence of the factors on the time until the occurrence of the termination of the contract in PHC. Backward selection procedure was the selection method adopted for the regression. To evaluate the statistical significance of the model coefficient Wald statistic was used and to examine the proportional hazards assumption for a Cox regression we used graphical diagnostics based on the scaled Schoenfeld residuals from coxph package in $\mathrm{R}$.

All tests considered a bidirectional $\alpha$ of 0.05 and a confidence interval (CI) of $95 \%$ and were performed with computational support from the software IBM SPSS 25 (Statistical Package for the Social Sciences), R-GUI version 3.6.2 (http://www.r-project.org/) Excel 2016 ${ }^{\circledR}$ (Microsoft Office).

\section{Results}

The profiles of the 1378 physicians enrolled between 2001 and 2016 are shown in Table 1. From the total of physicians, 725 [52,6\%(CI95\%50,0\%-55,2\%)] were female, the mean age at enrollment was 32,6 years $( \pm 9,25)$, the minimum age being 22 years and the maximum 78 years and only $130[9,4 \%(\mathrm{CI} 958.0-11.1 \%)]$ remained in the services of the PHC of the Santa Marcelina Institution until December 2016. 
Table 1 Distribution of the physicians that are being analyzed in the study, according to the selected variables, including absolute frequency, relative frequency and confidence interval of $95 \%$ (Cl 95\%)

\begin{tabular}{|c|c|c|}
\hline Variable & $N$ & $\%$ \\
\hline \multicolumn{3}{|l|}{ Gender } \\
\hline Female & 725 & $52.6 \%$ \\
\hline Male & 653 & $47.4 \%$ \\
\hline \multicolumn{3}{|l|}{ Age } \\
\hline$\leq 25$ years & 269 & $19.5 \%$ \\
\hline $25--\mid 30$ years & 492 & $35.7 \%$ \\
\hline$\geq 30$ years & 617 & $44.8 \%$ \\
\hline \multicolumn{3}{|l|}{ The year of employment } \\
\hline$<2005$ & 217 & $15.7 \%$ \\
\hline | 2010 & 526 & $38.2 \%$ \\
\hline $2010--\mid 2015$ & 499 & $36.2 \%$ \\
\hline$\geq 2015$ & 136 & $9.9 \%$ \\
\hline \multicolumn{3}{|l|}{ Working Hours } \\
\hline 40 h/weekly & 1079 & $78.3 \%$ \\
\hline$<40 \mathrm{~h} /$ weekly & 299 & $21.7 \%$ \\
\hline \multicolumn{3}{|l|}{ Modality of working ${ }^{a}$} \\
\hline ESF & 1222 & $88.7 \%$ \\
\hline UBS & 156 & $11.3 \%$ \\
\hline \multicolumn{3}{|l|}{ Initial wage ${ }^{b}$} \\
\hline$\leq 1.052 B G l$ & 684 & $49.6 \%$ \\
\hline$>1.052 B G l$ & 694 & $50.4 \%$ \\
\hline \multicolumn{3}{|l|}{ Years since graduation } \\
\hline$\leq 2$ years & 743 & $53.9 \%$ \\
\hline$>2$ years & 635 & $46.1 \%$ \\
\hline \multicolumn{3}{|l|}{ City of origin } \\
\hline São Paulo & 1077 & $78.2 \%$ \\
\hline Others & 301 & $21.8 \%$ \\
\hline \multicolumn{3}{|l|}{ School of graduation } \\
\hline Public & 336 & $28.1 \%$ \\
\hline Private & 858 & $71.9 \%$ \\
\hline \multicolumn{3}{|l|}{ Local of graduation } \\
\hline City of São Paulo & 195 & $16.3 \%$ \\
\hline Other municipalities & 999 & $83.7 \%$ \\
\hline \multicolumn{3}{|l|}{ Medical Specialty ${ }^{c}$} \\
\hline Non specialist & 1232 & $89.4 \%$ \\
\hline Specialist & 146 & $10.6 \%$ \\
\hline \multicolumn{3}{|l|}{ Medical Residency ${ }^{d}$} \\
\hline No & 1099 & $88.1 \%$ \\
\hline Yes & 149 & $11.9 \%$ \\
\hline \multicolumn{3}{|c|}{ Specialty at the end of study } \\
\hline Non specialist & 754 & $55.0 \%$ \\
\hline Specialist & 617 & $45.0 \%$ \\
\hline \multicolumn{3}{|l|}{ TEC-TEC } \\
\hline Yes & 1248 & $90.6 \%$ \\
\hline No & 130 & $9.4 \%$ \\
\hline
\end{tabular}

The Big Mac Index (BMI) created in 1986, calculated by The Economist, is an index based on the price of the Big Mac sandwich in more than 100 countries to explain the economy concept of parity in the purchasing power
Table 1 (continued)

a Work modality in PHC: ESF FHS - Family Health Strategy and BCU - Basic Care Unit

${ }^{\mathrm{b}}$ Monthly wage adjusted by BGI - Big Mac Index

${ }^{C}$ Medical specialty at the initial time of the contract

${ }^{d}$ Medical Residency concluded after a minimum of 3 years after the end of the contract

These physicians were followed for a total of $2.577,52$ years. The median time of observation was of 1,87 years $( \pm 2,29$ years) with a mean of 1,13 years (IIQ 0,45 a 2,17years). A time distribution of the follow-up can be visualized in Fig. 2a. A density of the incidence of ending a contract of the service, was of 484,3 personsyear (CI95\% 458,0-511,7).

The mean time until TEC was 2,14years (CI95\% $1,98-2,29$ years) with a median of 1,17 years [(CI95\% 1,05-1,28years)] (Fig. 2a). The probability of ending the contract in the first year is $45 \%$, increasing in the following years, with $68 \%$ in the second year, $78,5 \%$ in the third year and $84,2 \%$ in the fourth year, arriving to $89 \%$ of physicians that end their contract in the fifth year of followup (Fig. 2b).

Crude analysis showed that the following factors were significantly associated with TEC rate: age at initial employment, working hours, modality of unit, initial wage, time since graduation (years) and conclusion of the medical residency in up until 3 years after the end of the contract. The impact of each variable is described in detail in the Table 2.

The adjusted analysis resulted in six distinct models (Table 3). All models present significative explanation $(p<0,001)$ in relation to the empty model. In the model VI, the best one, four variables remained statistically significant: a) working hours of $40 \mathrm{~h} /$ week $\mathrm{HR}=1,71$ [(CI95\%1,4-2,09), $p<0,001]$; b) initial wage $\leq 1.052$ BGI HR $=1,87$ [(CI95 1,64-2,15), $p<0,001$; c) time since graduation $\leq 2$ years $H R=1,36$ [(CI95 1,18$1,56), p<0,001]$; and d) conclusion of medical residency up until 3 years after the end of the contract $\mathrm{HR}=1,69$ [(CI95 1,40-2,04), $p<0,001]$.

\section{Discussion}

Top of form

The present study strongly highlights the high turnover of physicians in PHC services in the East Zone of São Paulo. The average time until the termination of the contract was 2.14 years, that is, the professionals remained around 2 years in the services, although some individuals who stayed longer or very short periods in the PHC services influence this average. Almost half of the professionals left PHC shortly after admission (1.17 year). In other words, after hiring a medical professional, the probability 

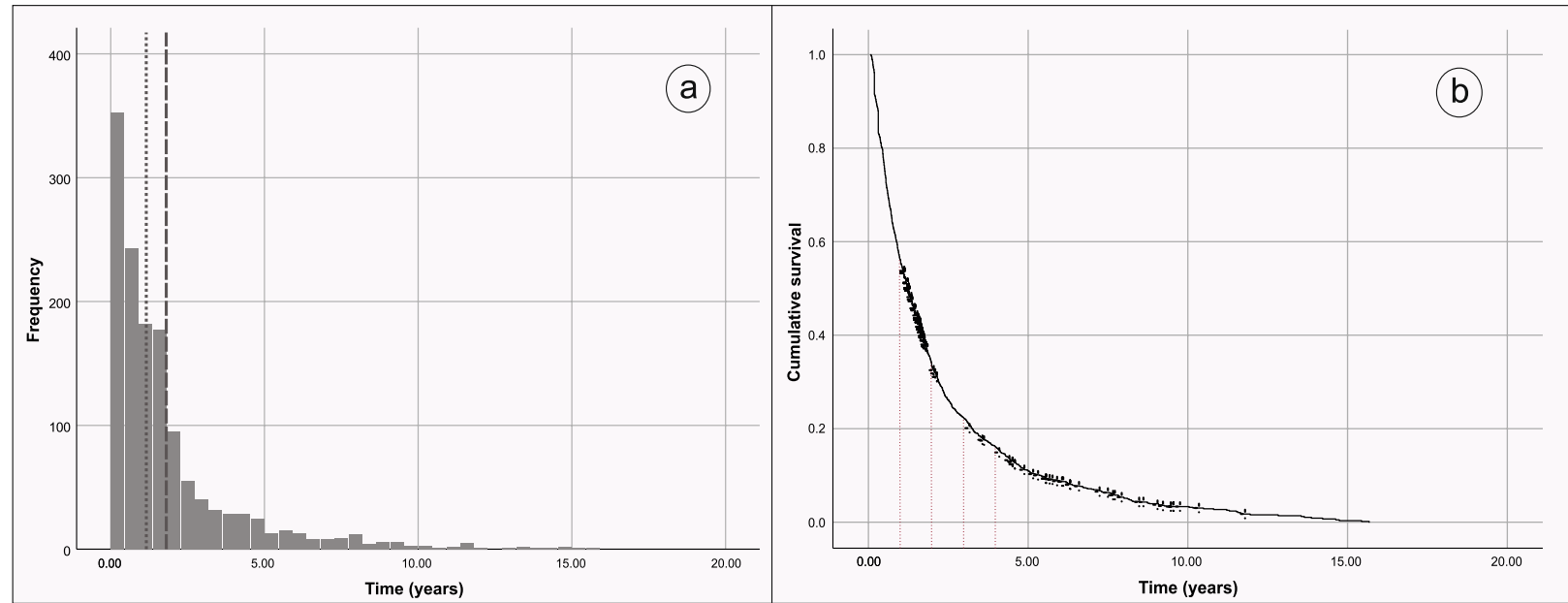

Fig. 2 Characterization of follow-up time and cumulative survival in the set of physician enrolled patients. a the median is represented by the dotted line. The mean is represented by the dashed line. $\mathbf{b}$ dashed lines represent the years completed until a follow-up of 5 years

of termination of his contract in the first year is $45 \%$. In 5 years, this probability rises to almost $90 \%$. Thus, only $10 \%$ of all active medical workforce remained in the services after 5 years of study follow-up.

Among the individual characteristics of the physicians studied here, the homogeneity of the gender variable was noted, with a slight female predominance: $52.6 \%$ of the PHC physicians at the follow-up were women. Though alone this data does not reflect the phenomenon of feminization of medicine, the Brazilian medical literature has already reported this process [35].

Regarding the age of doctors at the time of hiring, the group studied is quite young: $55.2 \%$ were under 30 years old. Although the profession's youth in Brazil is a trend, in the total population of doctors in the country, in this same age group (up to 29 years) are $42.6 \%$ of professionals [35]. Brazil has witnessed in the last decade the opening of many new private medical schools, including the city of São Paulo, one of them Santa Marcelina, The increased supply of newly graduated doctors, combined with the large availability of vacancies in the municipality's PHC, could lead to an even younger profile of the occupants of these jobs. Direct entry into the labor market, either because of difficulty in accessing a specialty residency, or the desire for more immediate financial gains (need to pay off public or private educational debts assumed at undergraduate level), is a phenomenon that needs to improve considering its possible impact not only on the longevity in PHC services, but also on the quality of care provided to the population [35-42],

Younger individuals, $\leq 25$ years, averaged 1.4 years in PHC services, while those aged 30 and over remained for 2.7 years. However, when adjusting the final model, age was not significant as a disengagement factor. Collinear to age, the time since graduation was relevant, with statistical significance, in the dismissal of doctors, and those graduated less than 2 years spent less time in PHC services, with a mean of 1.7 years.

Most of the physicians (78\%) had a 40-h workweek, a workload that reached $89 \%$ of the FHS doctors. The workload, as shown, is a contributing factor to the TEC. Doctors on a 40-h weekly basis had a significantly higher occurrence of TEC. Previously exclusively set at $40 \mathrm{~h}$ per week by federal determination [48], the journey of doctors in the PHC and FHS gained other possible configurations over the years, being allowed a workload of 20 or $30 \mathrm{~h}$ per week as of 2011 [49].

As with the full 40-h workday, the higher starting salary remained significant after adjustment as a factor of lower severance. Two variables, the 40 -h workday and the highest salary, are related, since salaries are largely proportional to the hours hired or worked.

PHC Santa Marcelina has already adopted a salary additions policy for districts in the East Zone that have greater difficulty in attracting doctors, such as Itaim, Guaianases and Tiradentes, due to the great distance of these regions to the city center. The practice of different wages within the same institution is a sensitive theme that runs into labor laws and can lead to greater wage inequalities between doctors and other professionals equally essential to PHC [50]. It has been shown that salary is a factor of attraction in PHC [23] but is insufficient to guarantee its permanence in medium and long term [22].

It was found in the study that the vast majority of doctors $(88.1 \%)$, upon joining the PHC service, had no 
Table 2 Estimates of the mean and median of the time frame until the occurrence of the end of the contract according with the different factors of the study including the confidence interval of 95\% (CI 95\%) and the descriptive level

\begin{tabular}{|c|c|c|c|c|c|c|}
\hline & Total & End of contract & $\%$ & Mean (Cl95\%) & Median (Cl95\%) & $p$-value* \\
\hline \multicolumn{7}{|l|}{ Gender } \\
\hline Female & 725 & 658 & $90.8 \%$ & $2.1(1.9-2.3)$ & $1.1(1.0-1.3)$ & \multirow[t]{2}{*}{0.529} \\
\hline Male & 653 & 590 & $90.4 \%$ & $2.2(2.0-2.4)$ & $1.2(1.0-1.4)$ & \\
\hline \multicolumn{7}{|c|}{ Age at initial employment } \\
\hline$\leq 25$ years & 269 & 248 & $92.2 \%$ & $1.4(1.2-1.6)$ & $0.8(0.6-1.0)$ & \multirow[t]{3}{*}{$<0.001$} \\
\hline $25--\mid 30$ years & 492 & 456 & $92.7 \%$ & $1.8(1.6-2.1)$ & $1.1(0.9-1.3)$ & \\
\hline$\geq 30$ years & 617 & 544 & $88.2 \%$ & $2.7(2.4-3.0)$ & $1.5(1.3-1.7)$ & \\
\hline \multicolumn{7}{|l|}{ Working Hours } \\
\hline $40 \mathrm{~h} /$ weekly & 1079 & 999 & $92.6 \%$ & $2.0(1.9-2.2)$ & $1.1(1.0-1.2)$ & \multirow[t]{2}{*}{0.002} \\
\hline$<40 \mathrm{~h} /$ weekly & 299 & 249 & $83.3 \%$ & $2.6(2.2-3.0)$ & $1.5(1.1-1.9)$ & \\
\hline \multicolumn{7}{|l|}{ Modality of Unit } \\
\hline FSH & 1222 & 1117 & $91.4 \%$ & $2.1(1.9-2.2)$ & $1.2(1.0-1.3)$ & \multirow[t]{2}{*}{0.019} \\
\hline$T B C U$ & 156 & 131 & $84.0 \%$ & $2.7(2.1-3.2)$ & $1.5(1.0-1.9)$ & \\
\hline \multicolumn{7}{|l|}{ Initial wage $e^{* *}$} \\
\hline$\leq 1.052 B G 1$ & 684 & 612 & $89.4 \%$ & $1.5(1.4-1.7)$ & $0.8(0.7-0.9)$ & \multirow[t]{2}{*}{$<0.001$} \\
\hline$>1.052 \mathrm{BGl}$ & 698 & 632 & $90.5 \%$ & $2.6(2.3-2.8)$ & $1.5(1.4-1.7)$ & \\
\hline \multicolumn{7}{|c|}{ Time since graduation (years) } \\
\hline$\leq 2$ years & 743 & 669 & $90.0 \%$ & $1.7(1.5-1.8)$ & $1.0(0.8-1.1)$ & \multirow[t]{2}{*}{$<0.001$} \\
\hline$>2$ years & 635 & 579 & $91.2 \%$ & $2.6(2.4-2.9)$ & $1.5(1.3-1.7)$ & \\
\hline \multicolumn{7}{|l|}{ City of residence } \\
\hline São Paulo & 1077 & 983 & $91.3 \%$ & $2.1(2.0-2.3)$ & $1.2(1.1-1.3)$ & \multirow[t]{2}{*}{0.975} \\
\hline Others & 301 & 265 & $88.0 \%$ & $2.1(1.8-2.4)$ & $1.1(0.9-1.3)$ & \\
\hline \multicolumn{7}{|c|}{ School of graduation } \\
\hline Public & 336 & 310 & $92.3 \%$ & $2.1(1.8-2.4)$ & $1.0(0.8-1.2)$ & \multirow[t]{2}{*}{0.852} \\
\hline Private & 858 & 785 & $91.5 \%$ & $2.0(1.8-2.2)$ & $1.1(1.0-1.2)$ & \\
\hline \multicolumn{7}{|c|}{ Local of graduation } \\
\hline São Paulo & 195 & 171 & $87.7 \%$ & $1.9(1.6-2.1)$ & $1.3(1-1.5)$ & \multirow[t]{2}{*}{0.990} \\
\hline Other locals & 999 & 924 & $92.5 \%$ & $2.0(1.9-2.2)$ & $1.1(1-1.2)$ & \\
\hline \multicolumn{7}{|c|}{ Specialty at the time of employment } \\
\hline Non specialist & 1232 & 1113 & $90.3 \%$ & $2.1(2.0-2.3)$ & $1.1(1.0-1.2)$ & \multirow[t]{2}{*}{0.199} \\
\hline Specialist & 146 & 135 & $92.5 \%$ & $2.3(1.9-2.7)$ & $1.5(1.2-1.9)$ & \\
\hline \multicolumn{7}{|c|}{ Medical Residency*** } \\
\hline No & 1099 & 1099 & $100.0 \%$ & $1.9(1.8-2.0)$ & $1.1(1.0-1.2)$ & \multirow[t]{3}{*}{$<0.001$} \\
\hline Yes & 149 & 149 & $100.0 \%$ & $0.8(0.7-1.0)$ & $0.7(0.6-0.7)$ & \\
\hline General & 1371 & 1242 & $90.6 \%$ & $2.1(2.0-2.3)$ & $1.2(1.1-1.3)$ & \\
\hline
\end{tabular}

The variables of the year on contract and actual specialty were not analyzed based on criteria from the researchers

* $p$-value calculated by the method of Log Rank (Mentel-Cox)

${ }^{* *}$ Monthly wage adjusted according to Big Mac Index

${ }^{* * *}$ Conclusion of Medical Residency up until 3 years after the end of the contract

medical specialty, i.e. had not completed a residency program or obtained the title of specialist by the Medical Society. There is usually no requirement for any specialty title to occupy the position of physician in PHC services. Job selection and hiring processes refer to "general practitioners", understood as the professional with a general medical background, i.e., the doctor with a completed degree and registration in the regional medical council.
The lack of specialization at the time of admission could be explained by the low average age of the physicians in this study. That is, for many, there was still not enough time to complete the specialization. It is also known that there are not enough Medical Residency positions for all medical graduates; paradoxically, there is a low demand for Family and Community Medicine Residency vacancies, a specialty that has insufficient 


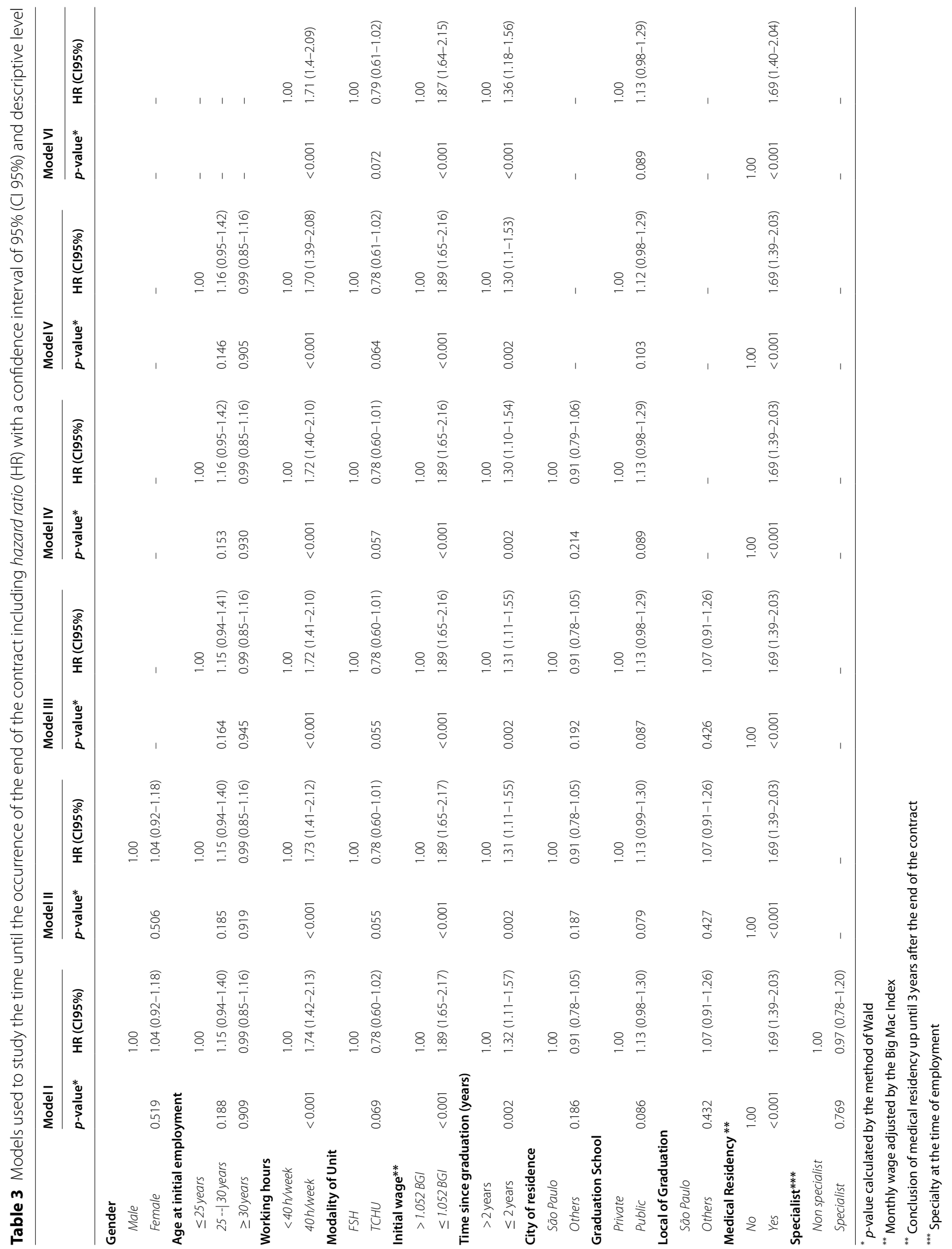


specialists to supply the jobs of doctors at PHC. Some municipalities in southern Brazil, such as Florianopolis, exception to the rule, insert in the contracting notices for FHS, the residency criterion or specialist title, aiming at a higher qualification of PHC human resources [51].

Among the findings of the study, $11.5 \%$ of physicians (who were not specialists at the time of admission) completed a residency within 3 years after the termination of contract in the PHC Santa Marcelina. This was a factor of strong impact on TEC, indicating that for this group of physicians, work in PHC may have been merely a transition between the end of graduation and beginning of residency, often in non-PHC specialties.

The percentage of specialists among admission (only $12 \%)$ increased significantly among those who were discharged; $45 \%$ of physicians who left PHC services throughout the study had a specialist title until 2016, the last year of follow-up. After leaving PHC, they specialized mainly in Gynecology and Obstetrics (13.2\%), Pediatrics (12.9\%), Family and Community Medicine (12.4\%) and Clinical Medicine (11.0\%). Although specialties are all suitable and relevant to $\mathrm{PHC}$, it is noteworthy that Family and Community Medicine was not the priority choice.

Therefore, it should be a matter of concern for the human resources policies in PHC the entry of large numbers of young doctors, recent graduates, without specialization and with post-retirement professional choices unrelated to work and PHC goals.

Although the number of doctors in Brazil has been growing exponentially, increasing 3.5 times more than the population between 1980 and 2010 [52], the persistent increase in the number of doctors did not benefit homogeneously all Brazilian citizens [42]. The city of São Paulo had 59,934 doctors [35] in professional activity in 2018, registered with the Regional Council of Medicine (CRM), a ratio of 4.98 doctors per 1000 inhabitants, compared to capitals with the highest concentrations of doctors in the world and our study showed lack of these professionals in the periphery of the same city. The "Mais Médicos" federal Program (More Doctors) created in 2013 [53], and its successor, in 2019, the "Médicos pelo Brasil" (Doctors for Brazil) Program [54] have given rise to important policy debates but still haven't resulted in a full coverage of PHC.

The findings of the present study point to concrete obstacles to the expansion of PHC, whose proportion of population coverage is insufficient, even in the city of São Paulo, since it does not reach $50 \%$ in the region studied. Even when overcome, the difficulty of hiring doctors in $\mathrm{PHC}$ is compounded by the high turnover of those who enter the services. Leaving after a short-term stay constantly deflects FHS teams or leaves open jobs at UBSs, a phenomenon that requires extra efforts and replacement costs that are not always successful.

Some of the attributes of PHC are compromised with this dynamic, such as the ability to solve the vast majority of the population's health problems and continuousness, which presupposes continuity of care, building bonds and accountability between professionals and users over time, permanently and consistently.

Studies have also shown that high staff turnover at PHC has a financial impact that includes the actual cost of entering and leaving staff, the cost of temporary replacements, as well as the cost of training, immersion activities, and alignment with care lines and the organization of services [55]. Overworking remaining professionals and breaking ties among the PHC team are other possible effects of physician turnover. On the population side, as the services most affected are those in regions of greatest social vulnerability, the vicious cycle of the lowest care associated with the worst health indicators seems to support a feedback system [56].

The methodological choice of physician dismissal measurement through the survival curve allowed the use of all study participants, regardless of the date of entry. Such methodology has been used in other countries [57-60] and in Australia, survival curves are essential as a methodology to track the effectiveness of national health manpower policies [58]. Retention in both cases (before and after retention policies) was higher than that observed in this study. Russell et al. [59] were able to demonstrate, through survival analysis techniques, the influence of factors associated with geographic location and population size on the retention phenomenon of physicians.

In Brazil, literature from the last decade has highlighted the inequalities in the supply and distribution of doctors, as well as the official policies for the establishment and provision of doctors implemented throughout the history of the health system. The high turnover of physicians in PHC services in Brazil is associated with multiple factors that generate professional dissatisfaction, such as inadequate working conditions, excessive workload, low pay and lack of job, career and salary plans [61-65]. The reasons that may favor the permanence are the identification with the PHC, the professional vocation and the perspective of serving the community $[25,37,44,51]$.

Resistance factors to exclusive dedication or permanence in a single workplace in PHC must also be considered as the characteristics of the medical profession in Brazil, are defined by the double public and private practice [45] and by multiplicity of work relationships (almost half of doctors have three or more jobs), long working hours (two thirds of doctors work more than $40 \mathrm{~h}$ per week), working shifts ( $45 \%$ make at least one 
shift per week), beyond the prospect of higher incomes that is usually only achieved through accumulation of jobs and activities. According to the Medical Demography in Brazil [66], the average physician's workload is more than $50 \mathrm{~h}$ per week, and almost a third of professionals work more than $60 \mathrm{~h}$ per week. Doctors work, on average, in three different jobs, with more than $30 \%$ accumulating four or more contracts. The professional usually occupies more than one job in UHS, often hired by more than one employer in the same municipal network. Most doctors working in the public sector share their work schedule with a private practice or practice in the private sector. It should be considered that in the city of São Paulo there is a large and diverse private network that employs part of the doctors who simultaneously work for the UHS $[45,66]$.

Throughout the history of the Brazilian health system, many governments have attempted to ensure the supply of doctors in PHC and other levels of care [67-70], including the Rondon Project, the Internationalization of Health Work (PITS), the Program to Support the Training of Specialist Physicians in Strategic Areas (ProResidency), the Appreciation Program for Primary Care Professionals (PROVAB). The two most recent federal medical provision programs, "Mais Médicos" and "Médicos pelo Brasil" [53, 54], did not use in their conceptions and legal frameworks evidence on physician turnover and permanence in $\mathrm{PHC}$, but both set criteria for municipalities' eligibility that would benefit from the programs [39-54, 66].

A strength of the study was the possibility of the integration of the human resources department's administrative database of the medical contracting organization in PHC with the most comprehensive study database, Medical Demography in Brazil, which allowed for an unprecedented approach to information and characteristics of physicians not reached by the isolated databases. This permitted the use of a large number of physicians over a long time period. However, this study has limitations, the main one being the limit range of findings, restricted to the available data and the variables selected for analysis, and the use of secondary data only, always subject to incompleteness of information and lack of systematization of records such as the authorization of doing less than $40 \mathrm{~h} /$ week was approved in 2011, 5 years after the study beginning that could be a confounding factor not measured thoroughly. This study could be extended to all São Paulo PHC and could be an interesting observatory for prospective cohort. A qualitative study could amplify the range of variables.

The turnover of doctors in PHC, is multifactorial. Various individual characteristics of physicians, service administrators and employers, as well as geographical, professional, financial and educational factors, are associated with retention of physicians in PHC [71-76]. Higher turnover has also been related to job dissatisfaction, conflicts between work and family care [77], as well as stress and burnout in a professional setting $[78,79]$.

Therefore, there are several research fronts and quantitative and qualitative methodologies that need to be considered for the systemic and complete approach to the problem. In the case studied, information related to physicians' personal choices, perception of security and violence in the East Zone, and opinion about the management institution's profile and conduct, just to name three examples of topics not reached by secondary data, would be relevant to a better understanding of physicians' withdrawal and permanence factors in PHC services.

\section{Conclusions}

PHC in UHS in the East Zone of the city of São Paulo has been occupied by a medical workforce with a majority profile of young graduates, without specialization, with little or no previous professional experience, who remain for a short time or leave early on the services.

The study shows the relevance of characteristics of the work contract (part-time work less than $40 \mathrm{~h}$ per week and higher initial salaries), individual characteristics (the fact that the doctor has a short time since graduation) and personal or professional choices (the termination of employment to attend medical residency).

Strategies within human resources policies to further attract and retain physicians must be combined and multiple, capable of acting on both modifiable factors at the time of job posting and hiring (eg. Salary, working hours and working conditions) and by less modifiable factors by employers upon admission (personal determination to study a certain medical specialty, for example).

\begin{abstract}
Abbreviations
95\%Cl: 95\% confidence intervals; AMB: Brazilian Medical Association; BMI: Big Mac Index; CNRM: National Commission of Medical Residency; CRM: Medical Regional Councils; TEC: Early termination of contract; FHC: Family Health Care program; FHS: Family Health Strategy; HDI: Human development index; HR: Hazard Ratio; LDB: Law of Directions and Bases for Education; PHC: Primary health care; SPSS: Statistical Package for the Social Sciences; UHS: Unified Health System; THU: Traditional Health Care Unit.
\end{abstract}

\section{Supplementary Information}

The online version contains supplementary material available at https://doi. org/10.1186/s12913-022-07517-1.

Additional file 1. 


\section{Acknowledgements \\ Not applicable.}

\section{Authors' contributions}

MMMB participated in the conception of the study, participated in the analysis, and drafted the manuscript. AJFC participated in the conception, participated in the analysis, and revised the final version. MCS participated in the conception of the study and revised the final manuscript. The author(s) read and approved the final manuscript.

\section{Funding}

Not applicable. The study was partially funded by the PAHO/MS/FMUSP partnership (SCON 2020-00001).

\section{Availability of data and materials}

The datasets generated and/or analyzed during the current study are not publicly available due to ethical issues related to participant confidentiality imposed by the Ethics Committee of the medical School of the University of São Paulo. Data from this paper are available upon request to the Ethics Committee of the medical School of the University of São Paulo. Mailing address: 251 Dr. Arnaldo Avenue- Cerqueira César - 01246-000 - São Paulo - SP - Brazil. Phone: + 55 (11) 3893-4401: Dr. Maria Aparecida Azevedo Koike Folgueira.

\section{Declarations}

\section{Ethics approval and consent to participate}

The research followed all ethical parameters required by the Resolution $\mathrm{N}^{\circ}$ 466/2012 of the National Research Ethics Commission of the National Health Council and was approved by the Research Ethical Committee of the Medical Faculty of São Paulo University (\#66147417.0.0000.0065). Prior to the start of the study, written consent and the required administrative permissions were obtained from the Santa Marcelina authorities to access human resource data. The IRB waived the use of the informed consent because the data accessed did not contain information that would allow personal identification. Confidentiality and privacy of all physician's data was ensured, used solely and exclusively as a whole for statistical purposes.

\section{Consent for publication}

Not applicable.

\section{Competing interests}

The authors declare that they have no competing interests.

\section{Author details}

${ }^{1}$ Program of Collective Health, Faculty of Medicine of the São Paulo University (FMUSP), São Paulo, SP, Brazil. '² Department of Gastroenterology, Faculty of Medicine of the São Paulo University (FMUSP), São Paulo, SP, Brazil. ${ }^{3}$ Brazilian Medical Demography Research Group, Faculty of Medicine of the São Paulo University (FMUSP), São Paulo, SP, Brazil. ${ }^{4}$ Department of Preventative Medicine, Faculty of Medicine of the São Paulo University (FMUSP), São Paulo, SP, Brazil. ${ }^{5}$ Evidence Based Medicine Discipline, Santa Marcelina Faculty, São Paulo, SP, Brazil.

Received: 9 March 2021 Accepted: 11 January 2022

Published online: 04 February 2022

\section{References}

1. WHO, World Health Organization. Building the primary health care workforce of the 21st century. Geneva: Building the primary health care workforce of the 21st century; 2018. https://apps.who.int/iris/handle/ $10665 / 328072$.

2. G20. Berlin Declaration of the $\mathrm{G} 20$ health ministers - together today for a healthy tomorrow. G20 Germany 2017. Berlin; 2017. p. 19-20. Available from http://www.g20.utoronto.ca/2017/170520-health-en.pdf. Accessed 12 Dec 2019

3. Beard TC, Redmond S. DECLARATION OF ALMA-ATA. International Conference on Primary Health Care, Al ma-Ata; 1978 Sept 6-12; Union of Soviet Socialist Republics: The Lancet; 1979.
4. WHO, World Health Organization. Forum 2017 Tokyo Declaration on universal health coverage. Geneva; 2017.

5. Campbell J, Buchan J, Cometto G, David B, Dussault G, Fogstat H, et al. Human resources for health and universal health coverage: fostering equity and effective coverage. Bull World Health Organ. 2013b;91(11):853-63.

6. Lopes MA, Almeida AS, Almada-lobo B. Handling healthcare workforce planning with care: where do we stand? Hum Resour Health. 2015:13(1):38.

7. WHO, World Health Organization. Global strategy on human resources for health: workface 2030. Geneva: Global strategy on human resources for health: workface 2030; 2016. https://apps.who.int/iris/bitstream/handle/ 10665/250368/9789241511131-eng.pdf.

8. WONCA, Wonca Rural Health. World Organization of Family Doctors world rural health conference; 2018 Apr 26-29; Índia; 2018.

9. Ono T, Schoenstein M, Buchan J. Geographic imbalances in doctor supply and policy responses. Working papers; 2014. https://doi.org/10.1787/ 5jz5sa5ls1wl-en.

10. Poghosyan L, Liu J, Shang J, D’Aunno T. Practice environments and job satisfaction and turnover intentions of nurse practitioners. Health Care Management Ver. 2017;42(2):162-71.

11. OECD, Organization for Economica Co-operation and Development. Health workforce policies in OECD countries: right jobs, right skills, right places. Paris: OECD Health Policy Studies, OECD Publishing Paris; 2016.

12. Mullan F. The metrics of the physician brain drain. N Engl J Med. 2005;353(17):1810-8

13. Dreesch N, Dolea C, Dal Poz MR, Goubarev A, Adamns O, Aregawi M, et al. An approach to estimating human resource requirements to achieve the millennium development goals. Health Policy Plan. 2005;20(5):267-76.

14. Bailey RJ, Dal Poz MR. Building the public health workforce to achieve health-related development goals: moving forward in collaboration. J Public Health Policy. 2010;31(4):494-7.

15. Grobler L, Marais BJ, Mabunda S. Interventions for increasing the proportion of health professionals practicing in rural and other underserved areas (review). Cochrane Database Syst Rev. 2005;21(1):CD005314.

16. Fritzen AS. Strategic management of the health workforce in developing countries: what have we learned? Hum Resour Health. 2007:5(1):4.

17. COGME, Council on Graduate Medical Education. Graduate Medical Education Strategic Plan Webinar and Conference Call. 2015.

18. Scheffler RM, Campbel J, Cometto G, Maeda A, Liu J, Bruckner TA, et al. Forecasting imbalances in the global health labor market and devising policy responses. Hum Resour Health. 2018;16(1):5.

19. Wilson NW, Couper ID, De Vries E, Reid S, Fish T, Marais BJ. A critical review of interventions to redress the inequitable distribution of healthcare professionals to rural and remote areas. Rural Remote Health. 2009;9(2):1060.

20. Pathman DE, Konrad TR, Dann R, Koch G. Retention of primary care physicians in rural health professional shortage areas. Am J Public Health. 2004;94(10):1723-9.

21. Oliveira APC, Dussault G, Craveiro I. Challenges and strategies to improve the availability and geographic accessibility of physicians in Portugal. Hum Resour Health. 2017:15(1):24.

22. OECD, Organization for Economic Co-operation and Development. The Looming Crisis In the Health Workforce how can oecd countries respond?; 2008

23. Stralen ACSV, Massote AW, Carvalho CL, Girard SN. Percepção de médicos sobre fatores de atração e fixação em áreas remotas e desassistidas: rotas da escassez. Physis. 2017;27(1):147-72.

24. Starfield B. Atenção Primária: equilíbrio entre necessidades de saúde, seviços e tecnologias. Brasília: Organização das Nações Unidas para a Educação a Ciência e a Cultura, Ministério da Sáude; 2002. Available from https://www.nescon.medicina.ufmg.br/biblioteca/imagem/0253.pdf

25. Santos LMP, Oliveira, Trindade JS, Barreto ICHC, Palmeira PA, Comes Y, et al. Implementation research: towards universal health coverage with more doctors in Brazil. Bull World Health Organ. 2017:95(2):103-12.

26. Diallo K, Zurn P, Gupta N, Dal Poz MR. Monitoring and evaluation of human resources for health: an international perspective. Hum Resour Health. 2003;1:3.

27. Brasil. Saúde da Família: uma estratégia para reorientação do modelo assistencial. Brasília: Ministério da Saúde, Secretaria de Assistência à Saúde, Coordenação de Saúde da Comunidade; 1997. Available from http://bvsms.saude.gov.br/bvs/publicacoes/cd09_16.pdf 
28. Lindelow M, Araujo EC. Universal health coverage for inclusive and sustainable development. Japan: World Bank Group; 2014. Available from http://documents.worldbank.org/curated/pt/199721468021280000/ pdf/912140WPOUHCOCOBox385329B0OPUBLICO.pdf>. Accessed 29 Ago 2017.

29. Gragnolati M, Lindelow M, Couttolenc B. Twenty years of health system reform in Brazil: an assessment of the Sistema Único de SaÚde. Washington, DC: The World Bank. https://doi.org/10.1596/978-0-8213-9843-2.

30. Macinko J, Dourado I, Aquino R, Bonolo Pde F, Lima-Costa MF, Medina $M G$, et al. Major expansion of primary care in Brazil linked to decline in unnecessary hospitalization. Health Aff. 2010;29(12):2149-60.

31. Mendes EV. As Redes de Atenção à Saúde. Brasília: Organização PanAmericana da Saúde, Organização Mundial da Saúde, Conselho Nacional de Secretários da Saúde; 2011.

32. Rodrigues RB, Silva NC, Rocha TAH. Atração e Retenção do Profissional Médico e os Desafios para a Estratégia Saúde da Família. XXXIV Encontro da ANPAD 2010 set 25-29; Rio de Janeiro, Brasil.

33. Campos FE, Machado MH, Girardi SN. A fixação de profissionais de saúde em regiões de necessidades. Divulg Saúde Debate. 2009:44:13-24

34. Perpétuo IHA, Oliveira AC, Ribeiro MM, Rodrigues RB. A categoria profissional dos médicos fatores condicionantes de sua atração e fixação na atenção primária à Saúde em Minas Gerais. Belo Horizonte: Observatório de Recursos Humanos em Saúde do NigOne, UFMG; 2009.

35. Scheffer MC, Cassenote A, Guilloux AGA, Biancarelli A, Miotto BA Mainardi GM. Demografia Médica no Brasil 2018. São Paulo: Departamento de Medicina Preventiva Faculdade de Medicina da USP. Conselho Regional de Medicina do Estado de São Paulo, Conselho Federal de Medicina; 2018a.

36. Pierantoni CR, Vianna CM, França T, Magnano C, Rodrigues MP. Rotatividade da força de trabalho médica no Brasil. Divulg Saúde Debate. 2015;39(106):637-47.

37. Gonçalves RJ, Soares RA, Troll T, Cyrino EG. Ser médico no PSF: formação acadêmica, perspectivas e trabalho cotidiano. Ver Brasi Educ Med. 2009;33(3):393-403.

38. Guglielmi MC. A política pública Saúde da Família e a permanência fixação do profissional em medicina: um estudo de campo em Pernambuco. Belo Horizonte: Tese [Doutorado em Saúde Coletiva] - Universidade do Estado do Rio de Janeiro; 2006.

39. Girardi SN, Carvalho CL, Araujo JF, Farah JM, Mass LWE, Campos LAB. Índice de escassez de médicos no brasil: estudo exploratório no âmbito da atenção primaria: NESCON, UFMG; 2008. Available from http://epsm. nescon.medicina.ufmg.br/dialogos2/Biblioteca/Artigos_pdf/Indice_de_ escassez_de_medicos_no_Brasil_estudo_exploratorio_no_ambito_da_ Atencao_Primaria.pdf. Accessed 27 Ago 2019

40. Hipgrave DB, Hort K. Dual practice by doctors working in south and East Asia: a review of its origins, scope and impact, and the options for regulation. Health Policy Plan. 2014;29(6):703-16.

41. McPake B, Russo G, Hipgrave D, Hort K, Campbell J. Implications of dual practice for universal health coverage. Bull World Health Organ. 2016:94:142-6.

42. Scheffer MC, Dal Poz MR. The privatization of medical education in Brazil: trends and challenges. Hum Resour Health. 2015;13:96.

43. Paim J, Travassos C, Almeida C, Bahia L, Macinko J. O sistema de saúde brasileiro: história, avanços e desafios. Lancet. 2011;6736(11):11-31.

44. Dal Poz MR, Varella TC, Santos MR. Formação em Saúde: Problemas e Tendências. Textos para discussão. Rio de Janeiro: Fundação Oswaldo Cruz; 2015.

45. Miotto BA, Guilloux AGA, Cassenote A, Mainardi GM, Russo G, Scheffer MC. Physician's sociodemographic profile and distribution across public and private health care: an insight into physicians' dual practice in Brazil. BMC Health Serv Res. 2018;18:299.

46. IBGE, Instituto Brasileiro de Geografia e Estatística. Censo demográfico 2010: Características gerais da população, religião e pessoas com deficiência. Rio de Janeiro: IBGE; 2010. Available from https://biblioteca. ibge.gov.br/visualizacao/periodicos/94/cd_2010_religiao_deficiencia.pdf. Accessed 27 Ago 2019

47. Drummond M, Bassichetto KC, Azevedo MMT, Grimm S. Indice de necessidades em SaÚde da Cidade de São Paulo. São Paulo: Secretaria Municipal da SaÚde, Coordenação de Epidemiologia e Informação CEInfo; 2010.
48. Ministério da Saúde (Brasil). Portaria n. 648, de 28 de março de 2006. Aprova a Política Nacional de Atenção Básica, estabelecendo a revisão de diretrizes e normas para a organização da Atenção Básica para o Programa Saúde da Família (PSF) e o Programa Agentes Comunitários de Saúde (PACS). Brasília, v. 143, n. 61, 2006. Seção 1, p.71-76.

49. Ministério da Saúde (Brasil). Portaria $n^{\circ}$. 2.027, de 25 de agosto de 2011 Altera a Portaria n 648/GM/MS, de 28 de março de 2006, na parte que dispõe sobre a carga horária dos profissionais médicos que compõem as Equipes de Saúde da Família (ESF) e na parte que dispõe sobre a suspensão do Piso de Atenção Básica (PAB). Diário Oficial da União. $2011 ; 1: 7$.

50. Lima FLT. A rotatividade dos profissionais na Estratégia Saúde da Família : um estudo sobre a microrregião de Itabira. Rio de Janeiro Tese [Mestrado em Saúde Pública] - Fundação Oswaldo Cruz; 2012.

51. Florianópolis. Edital $N^{\circ} 005 / 2019$. Processo Seletivo Simplificado para preenchimento de cargo de Médico de Família e Comunidade, para a execução de programa de saúde conveniado com Ministério da Saúde, conforme previsto no inc. III do art $2^{\circ}$ da Lei Municipal Lei ${ }^{\circ}$ 6690/2005

52. Scheffer MC, Cassenote A, Biancarelli A. Demografia Médica no Brasil: Cenários e Indicadores de Distribuição. São Paulo: Conselho Regional de Medicina do Estado de São Paulo, Conselho Federal de Medicina; 2013.

53. Brasil. Lei $n^{\circ} 12.871$, de 22 de outubro de 2013. Institui o Programa Mais Médicos, altera as Leis n 8.745, de 9 de dezembro de 1993, e n 6.932, de 7 de julho de 1981, e dá outras providências. Diário Oficial da União 23 out. 2013.

54. Brasil. Medida Provisória $n^{\circ} 890$, de $1^{\circ}$ de agosto de 2019. Institui o Programa Médicos pelo Brasil, no âmbito da atenção primária à saúde no Sistema Único de Saúde, e autoriza o Poder Executivo federal a instituir serviço social autônomo denominado Agência para o Desenvolvimento da Atenção Primária à Saúde. Diário Oficial da União 01 ago. 2019; 147-A:1.

55. Chisholm M, Russell D, Humphreys J. Measuring rural allied health workforce turnover and retention: what are the patterns, determinants and costs? Aust J Rural Health. 2011;19(2):81-8.

56. Hopkins TJ. US patients live longer in areas with more primary care doctors, study finds. BMJ. 2019:364-1804.

57. Assefa T, Haile T, Haile Mariam D, Mekonnen W, Derbew M. Survival analysis to measure turnover of the medical education workforce in Ethiopia. Hum Resour Health. 2017;15(1):23.

58. Bailey BE, Wharton RG, Holman CD. Glass half full: survival analysis of new rural doctor retention in Western Australia. Aust J Rural Health. 2016;24(4):258-64.

59. Russel DJ, Humphreys JS, McGrail MR, Cameron WL, Williams PJ. The value of survival analyses for evidence-based rural medical workforce planning. Hum Resour Health. 2013;11(1):65.

60. Russell DJ, Humphreys JS, Wakerman J. How best to measure health workforce turnover and retention: five key metrics. Aust Health Rev. 2012:36(3):290-5

61. Borrelli FRG. A rotatividade dos profissionais de saúde na zona rural de sergipe: um problema a ser enfrentado. Rio de Janeiro Tese [Mestrado em Medicina Preventiva] - Fiocruz; 2004.

62. Campos MV, Malik M. Satisfação no trabalho e rotatividade dos médicos do Programa de Saúde da Família. Rev Adm Pública. 2008;42(2):347-68.

63. Tomasi $E$, Facchini LA, Piccini $X$, Thumé $E$, Silva DS, Siqueira FV, et al. Perfil sócio-demográfico e epidemiológico dos trabalhadores da atenção básica à saúde nas regiões Sul e Nordeste do Brasil. Cad Saúde Pública. 2008;24(suppl 1):s193-201.

64. Maciel FR. Estrategias para a distribuição e fixação de médicos em sistemas nacionais de saúde: O caso Brasileiro. Rio de Janeiro: Tese [Doutorado em Saúde Coletiva] - Universidade do Estado do Rio de Janeiro; 2007.

65. Lopes EZ, Bousquat A. Fixação de enfermeiras e médicos na Estratégia SaÚde da Família, município de Praia Grande, São Paulo, Brasil. Rev Brasileira de MFC. 2011;6(19):118-24.

66. Scheffer MC, Biancarelli A, Cassenote A. Demografia Médica no Brasil 2015. São Paulo: Departamento de Medicina Preventiva Faculdade de Medicina da USP, Conselho Regional de Medicina do Estado de São Paulo, Conselho Federal de Medicina; 2015.

67. Craveiro I, Hortale V, Oliveira APC, Dal Poz M, Portella G, Dussalt G. The utilization of research evidence in health workforce policies: the 
perspectives of Portuguese and Brazilian National Policy-Makers. J Public Health. 2018;40(suppl_1):i50-6.

68. Kemper ES, Mendonça AVM, Sousa MF. Programa Mais Médicos: panorama da produção científica. Ciênc Saúde Coletiva. 2016;21 (9):2785-96.

69. Mourão Netto JJ, Rodrigues ARM, Aragão OC, Goyanna NF, Cavalcante AES, Vasconcelos MAS, et al. Programa Mais Médicos e suas contribuições para a saúde no Brasil: revisão integrativa. Rev Panam Salud Publica. 2018;42:1-7.

70. Girard SN, Van Stralen ACS, Celia JN, Maas LWD, Carvalho CL, Faria EO. Impacto do Programa Mais Médicos na redução da escassez de médicos em Atenção Primária à Saúde. Ciênc Saúde Coletiva. 2016;21 (9):2675:84

71. Kollar E, Buyx A. Ethics and policy of medical brain drain: a review. Swiss Med Wkly. 2013;143:w13845.

72. Afzal S, Masroor I, Shafqat G. Migration of health workers: a challenge for health care system. J Coll Physicians Surg Pak. 2012;22(9):586-7.

73. Castro Palaganas E, Spitzer DL, Kabamalan MM, Sanchez MC, Caricativo R, Runells $V$, et al. An examination of the causes, consequences, and policy responses to the migration of highly trained health personnel from the Philippines: the high cost of living/leaving — a mixed method study. Hum Resour Health. 2017:15(1):25.

74. Wright D, Flis N, Gupta M. The "Brain Drain" of Physicians: Historical antecedents to an ethical debate, c. 1960-79. Philos Ethics Humanit Med. 2008;3(1):24.

75. Russell DJ, McGrail MR, Humphreys JS. Determinants of rural Australian primary health care worker retention: a synthesis of key evidence and implications for policymaking. Aust J Rural Health. 2017;25(1):5-14.

76. Degen C, Li J, Angerer P. Physicians' intention to leave direct patient care: an integrative review. Hum Resour Health. 2015;3(1):74

77. Lu Y, Hu XM, Huang XL, Zhuang XD, Guo P, Feng LF, et al. The relationship between job satisfaction, work stress, work-family conflict, and turnover intention among physicians in Guangdong, China: a cross-sectional study. BMJ Open. 2017;7(5):e014894.

78. Willard-Grace R, Knox M, Huang B, Hammer H, Kivlahan C, Grumbach K. Burnout and health care workforce turnover. Ann Fam Med. 2019;17(1):36-41.

79. Albuquerque FJB, Melo CF, Araújo Neto JL. Avaliação da síndrome de burnout em profissionais da Estratégia Saúde da Família da capital paraibana. Psi Reflexão e Crít. 2012;25(3):542-9.

\section{Publisher's Note}

Springer Nature remains neutral with regard to jurisdictional claims in published maps and institutional affiliations.

Ready to submit your research? Choose BMC and benefit from:

- fast, convenient online submission

- thorough peer review by experienced researchers in your field

- rapid publication on acceptance

- support for research data, including large and complex data types

- gold Open Access which fosters wider collaboration and increased citations

- maximum visibility for your research: over $100 \mathrm{M}$ website views per year

At BMC, research is always in progress.

Learn more biomedcentral.com/submissions 